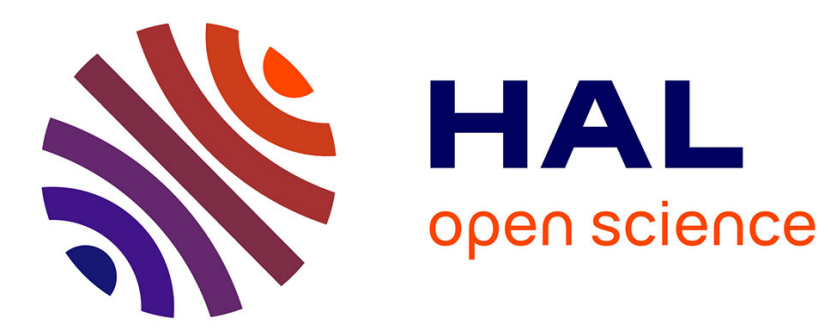

\title{
Dynamism and Change in the Possessive Classifier System of Iaai
}

Anne-Laure Dotte

\section{To cite this version:}

Anne-Laure Dotte. Dynamism and Change in the Possessive Classifier System of Iaai. Oceanic Linguistics, 2017, 56 (2), pp.339-363. 10.1353/ol.2017.0017 . hal-02877380

\section{HAL Id: hal-02877380 \\ https://hal.science/hal-02877380}

Submitted on 4 Sep 2020

HAL is a multi-disciplinary open access archive for the deposit and dissemination of scientific research documents, whether they are published or not. The documents may come from teaching and research institutions in France or abroad, or from public or private research centers.
L'archive ouverte pluridisciplinaire HAL, est destinée au dépôt et à la diffusion de documents scientifiques de niveau recherche, publiés ou non, émanant des établissements d'enseignement et de recherche français ou étrangers, des laboratoires publics ou privés. 


\title{
Dynamism and Change in the Possessive Classifier System of Iaai
}

\author{
Anne-Laure Dotte \\ THE UNIVERSITY OF NEW CALEDONIA
}

\begin{abstract}
Oceanic languages are well known for having rich systems of possessive classifiers occurring in indirect possessive constructions. This paper aims at analyzing the dynamism and change displayed in the possessive classifier system of Iaai, one of the twenty-eight Kanak languages spoken in New Caledonia. The study compares modern first-hand data with data and analysis from the reference grammar of Iaai written by Françoise Ozanne-Rivierre. The main purpose of the study is to compare speakers' possessive classifier repertoires and to identify sociolinguistic criteria (age; type of speaker; linguistic biography; and so on) that could explain any differences between them. Losses and accommodations within the modern system are studied in terms of linguistic changes (obsolescence versus resilience) combining real-time and apparent-time approaches.
\end{abstract}

1. PRESENTATION. ${ }^{1}$ This paper aims at studying the evolution of the possessive classifier system of Iaai, an Oceanic language of New Caledonia. First, I introduce the sociolinguistic and ethnolinguistic background of the study (1.1), providing some general considerations and terminology required for understanding the expression of possession in Oceanic languages (1.2). Second, I describe the possessive classifier system of Iaai and its main characteristics according to Ozanne-Rivierre (1976). This section details the system's inventory (2.1), its semantic scope (2.2), and the features of fluidity and variation inherent in such a system (2.3); and it outlines a quick comparison with Iaai's sister languages (2.4). The third part of the paper details the methodology used for the modern data collection, introducing the stimuli I created for the purpose of gathering possessive classifiers during fieldwork in New Caledonia (3.1), presents the speakers who participated in the experiment (3.2), and explains the theoretical framework for the complementary real-time / apparent-time approach used (3.3). I then present the results of the study

1. I am very grateful to the late Frank Lichtenberk for sharing with me his preprint articles and for his inspiring work on "relational classifiers" in Oceanic and Austronesian languages over the last 30 years. This paper is dedicated to his memory. I am very thankful to Alexandra Aikhenvald and an anonymous reviewer for their numerous and accurate insights and suggestions, and to John Lynch for his patience and support in the editorial process of this paper. I would like to express my appreciation to Colette Grinevald and Claire Moyse-Faurie for their helpful and wise comments on an earlier version of this paper. I thank also Emilie DotteSarout (ANU) and Mary Walworth (MPI) for their meticulous proofreading. Any errors that remain are my sole responsibility. 
and the different dynamics and changes in progress within the possessive classifier system of Iaai. Two main movements have been identified: obsolescence, with the loss of three previously attested classifiers (4.2), together with the decrease of speakers' individual repertoires (4.3); and resilience, with examples of the incorporation of neologisms, along with semantic extension (4.4). This section also shows how the methodology of the study has allowed us to acknowledge the existence of three additional classifiers that were undocumented in previous literature on Iaai (4.1). Finally, the last section (section 5) summarizes the study and its main conclusions.

1.1 GENERAL SOCIOLINGUISTIC BACKGROUND. New Caledonia is a place of great linguistic diversity. There are twenty-eight Kanak (that is, vernacular) languages and more than ten dialects, plus Tayo, a creole spoken on a small scale; dozens of allochthone languages due to more or less recent migrations; and French, the national and dominant language that serves as the lingua franca. All Kanak languages are members of the Oceanic branch of the Austronesian language family.

Iaai is one of these Kanak languages and is spoken on the island of Ouvéa (Loyalty Islands, New Caledonia) together with West Uvean, a Polynesian outlier (called Fagauvea locally), and French. Even if laai remains the daily spoken language at home, French prevails as the language for the administrative and public spheres, or when West Uvean and Iaai speakers lack common bilingual competencies.

Based on my own fieldwork observations and interviews in 2010 and 2012, I define Iaai as a threatened language (level 3 "endangered language" on the 5-level scale from UNESCO [2003]). It has around 4,000 native speakers ${ }^{2}$ (INSEE-ISEE 2009), with a large proportion - more than two thirds - living in the urban area of Nouméa, on Grande Terre, the main island of New Caledonia. In general, when Kanak families move to Nouméa, it disrupts the intergenerational transmission of their indigenous languages (see Barnèche 2005, and Moyse-Faurie, Rivierre, and Vernaudon 2012), and Iaai-speaking families are no exception. This kind of break in transmission and distance from one's indigenous language contributes to the strong linguistic insecurity that young Kanak have in speaking their ancestral language and is one reason for varying linguistic competencies between generations (Colombel and Fillol 2012; Dotte 2013:114-22).

1.2 INDIRECT POSSESSIVE CONSTRUCTIONS. Oceanic languages typically display two types of possessive constructions. ${ }^{3}$ One is a direct construction, where the possessor is immediately indexed by a suffix on the possessed noun. The second is an indirect construction and entails the use of a possessive classifier to which the possessor morpheme is suffixed. ${ }^{4}$

2. The census counts only speakers over 14 years old.

3. Polynesian languages treat possession very differently from other Oceanic languages. In these languages, the direct/indirect contrast has been substituted by a contrast between a possessive determiner $a$ for agentive-type relations versus a possessive determiner $o$ for patient-type relations, with, additionally, a determiner ' $i$ for whole-part relations (Moyse-Faurie 2004).

4. One of the reviewers rightly pointed out that Geraghty (1983) first used this terminology contrasting direct and indirect constructions in Fijian. 
This binary distinction is illustrated in the following examples in Iaai with direct construction in (1a) and indirect in (1b). ${ }^{5}$
(1) a. hinyö-k
mother-POS.1SG
'my mother'
b. haalee-k kuli
P.CL_PET-POS.1SG dog
'my dog (pet)'

Word order in possessive constructions in Iaai depends on the grammatical nature of the possessor. When the possessor is not lexically expressed, the possessive classifier precedes the possessed noun and carries the possessive suffix: $<$ Classifier - Pos.Suf - Possessed Noun $>$, as in example (1b) above. If the possessor is lexical, the possessed noun precedes the classifier with possessive suffix, and the possessor noun ends the construction: $<$ Possessed Noun - Classifier - Pos.Suf - Possessor Noun $>$, as in example (2a) below. Finally, when the possessor is expressed by a proper noun, the word order is similar to the preceding instance, but there is no possessive suffix on the classifier: $<$ Possessed Noun - Classifier - Possessor Proper Noun $>$, as in example (2b). dog P.CL_PET-POS.3SG child 'the child's dog (pet)'
(2) a. kuli haalee-ny wanakat
b. kuli haalee Aiawa dog P.CL_PET Aiawa 'Aiawa's dog (pet)'

Direct possessive constructions concern bound nouns that cannot appear without the possessive marker, while indirect possessive constructions draw on free nouns. ${ }^{6}$ Free nouns are lexically autonomous and constitute an open lexical class that can welcome neologisms and loan words.

In addition to supporting the possessor suffix, possessive classifiers ${ }^{7}$ can give semantic information on the formal properties of the possessed item (see Meyerhoff to appear); outline nominal categories based on lexical determination (see Franjieh 2012; Franjieh and von Prince 2011); ${ }^{8}$ or inform about the nature of the relationship expressed between possessor and possessed. In this case, possessive classifiers provide information about the ways items can be handled, consumed, or used by the possessor. Because of this, Lichtenberk $(1983,2009)$ calls them "relational classifiers." There is on this topic a longstanding discussion about whether classifiers in possessive constructions classify the function/relation or the possessed noun itself. Aikhenvald (2013: 20) marks the difference terminologically and argues that "relational classifiers categorize the relationship between the two nouns. Possessive classifiers categorize the Possessee." As far as the

5. In this paper, P.CL will be used to gloss possessive classifiers.

6. Following Lichtenberk (1985:103-8), "direct possessive constructions are normally used to express inalienable possession. ... Indirect possessive constructions are normally used to express alienable possession."

7. In a typological perspective, this kind of classifier is semantically distinguished from numeral or noun classifiers, as they classify primarily based on function rather than on physical (numeral classifiers) or material (noun classifiers) criteria (see Carlson and Payne 1989:11012 and Olness 1991 in Grinevald 2000:73).

8. These three studies (Meyerhoff to appear; Franjieh 2012; Franjieh and von Prince 2011) argue against the relational theory of classifiers in some Vanuatu languages and point out the importance of taking into account not only elicited data but also usage data in order to fully understand the situation-based motivation of speakers' strategy in classifier choice.

9. Accordingly, François (1999) talks about the "illusion of classifiers" that do not exactly classify the possessed, strictly speaking, but rather the nature of the possessive relation. 
specific case of Iaai is concerned, I consider that "relational classification" and "nominal classification" are both attested and that the Iaai possessive classifier system forms a "single integrated system" (Aikhenvald 2000:140-42).

Possessive classifiers have also been attested in languages of the Americas - see, for example, the Panare language in Venezuela (Payne and Payne 2014:82-86) - but it remains above all a typological characteristic of Oceanic languages. ${ }^{10}$ In Proto-Oceanic (POC), the binary contrast between direct and indirect constructions was already relevant and the consensus in the reconstructions agrees with (at least) three subtypes of indirect constructions: a classifier for edible items (*ka- for any kind of food nouns), a classifier for drinkable ones $\left({ }^{*} \mathrm{~m}^{(\mathrm{w})} \mathrm{a}\right.$ - for any kind of drink nouns), and a general classifier (*na-) (based on Lichtenberk to appear; Lynch, Ross, and Crowley 2002). Within Oceanic, Micronesian languages show maximal diversification of possessive classifiers systems (Carlson and Payne 1989), and in some of these languages the paradigm of classifiers can exceed twenty, as in Pohnpeian (Rehg and Sohl 1981), or even more than thirty, as in Chuukese (Benton 1968). In languages with such large possessive classifier inventories, their exact number is usually not easy to state because of different criteria of productivity and variation. In some languages, having "repeaters" (see Aikhenvald 2000:141; and 2.1 and 2.2.3 in this paper for Iaai) demonstrates that possessive classifiers can almost be an open class.

Possessive classifier systems are also well known to be culturally motivated because selected functions that are classified can refer to special activities or to socio-cultural conventions of specific importance for a given community (see Aikhenvald 2000:340-51; Craig 1986:285; Marnita 2016:163-66). In fact, environmental, cultural, or social changes can bring about changes in the systems of classifiers. This provides evidence that processes of cultural transformation play a significant role in linguistic change. When a traditional activity is no longer practiced, it is frequently attested that the specific classifier that was required to speak about this activity becomes obsolete (see 4.2).

This apparent variability and cultural dependence indicates the complexity of possessive systems in Oceanic languages and offers insights into their evolution, especially in the case of large systems of possessive classifiers that are considered open categories that are likely to be increased with new units if needed but, also, likely to be decreased with the abandonment of less useful ones. Furthermore, the sociolinguistic vitality of the language can also be responsible for linguistic changes in cases of obsolescence and can impact the unstable domain of classifiers (Craig 1986).

These are possible explanations as to why systems of classifiers are considered as moving linguistic systems and why changes were expected in Iaai. Linguistic changes are at the core of the present paper, which considers linguistic evolution in both diachronic and synchronic theoretical perspectives. First, the data are compared in a realtime study, confronting Ozanne-Rivierre's inventory (1976) with the one obtained through my own collection during recent fieldwork (Dotte 2013). ${ }^{11}$ Then, analysis is con-

10. For a history of classifier studies, see Grinevald (2015).

11. This paper is based on data collected during $\mathrm{PhD}$ thesis research funded by the Government of New Caledonia (Bourse d'Encouragement à la Recherche Universitaire, 2010-2013) and to fieldwork supported by two French research centers: DDL (UMR5596, CNRS) and LACITO (UMR7107, CNRS). 
ducted in apparent-time, comparing data obtained by the use of visual stimuli among a cohort of differently aged Iaai speakers.

\section{IAAI POSSESSIVE CLASSIFIER SYSTEM}

2.1 INVENTORY. Since the earliest descriptions of Iaai, linguists have highlighted the richness of its possessive classifier systems (Ray 1926; Leenhardt 1946; Tryon 1968; Ozanne-Rivierre 1976). As both the terminology referring to this topic and the inventory of classifiers differ from one author to the other, the study of Ozanne-Rivierre remains the most extensive, reliable, and recent. I based my study on the inventory of the twentythree possessive classifiers she described, and I will discuss later how my modern study revises the preexisting descriptions.

The list of these possessive classifiers is given in table 1. Classifiers are given with the third person singular suffix $-n \sim-n y .^{12}$ The lexical origin of these classifiers is often transparent and easy to establish. ${ }^{13}$ Furthermore, it has not lost much of its semantic motivation.

As the first linguists working on Iaai already noticed, this inventory must be considered as a nonfinite system because of its high degree of creativity: Leenhardt spoke of "extreme variety of possessive modalities" (1945:237-38), whereas Ozanne-Rivierre stated that "because some processes seem infinitely creative, ... it appears to us difficult, if not impossible, to draw up a closed list of possible different markers" (1976:189191). ${ }^{14}$ This almost infinite capacity to create possessive classifiers is largely due to "autoclassifiers" or "repeaters." These classifiers are bound nouns formed from the repetition of a free noun in an indirect possessive construction; for example, noon $n u$ 'his/her coconut tree' or mënyin men 'his/her strength" in Iaai. Some classifiers of a repeater type appear to have undertaken a grammaticalization path in that they accept nouns other than the repeated one, so long as the possessed item is semantically related to the repeated lexeme. For example, the possessive classifier noon, coming from $n u$ 'coconut tree', is also attested to mark possession of other kinds of planted or cultivated trees: noon wahanic 'his/her orange tree'; noon imanaapo 'his/her papaya tree'; and so on. Therefore, repeaters in Iaai do not pertain only to the semantic subtype of unique classifiers, but also to the specific classifier subtype (see 2.2.2 and 2.2.3).

2.2 SEMANTIC SCOPE OF THE CLASSIFIERS. Three semantic subtypes of classifiers are distinguished under the classificatory scope of categorized nouns. In Iaai, I distinguish one general, fourteen specific, and eight unique classifiers, following Grinevald's (2004:1017) terminology.

12. $-n y$ corresponds to the palatal nasal [n] and $-n$ to the dental nasal [n]. The allomorphic variation depends on the morphophonological context that precedes the suffix: $/ \mathrm{n} /$ becomes $[\mathrm{n}]$ when preceded by the long close-mid front unrounded vowel [e:].

13. Possessive classifiers in Iaai come, mainly, from verbs or free nouns. To a lesser extent, some come from bound nouns or prepositions. A small number of Iaai classifiers have uncertain lexical origins: this is the case for the general classifier anyin, whose lexical origin could reasonably be associated with unyi 'thing', but that remains uncertain (see Dotte 2013:245-48 for further details).

14. Translations from French originals throughout this paper are my own. 
TABLE 1. THE IAAI POSSESSIVE CLASSIFIERS REFERENCE SYSTEM ${ }^{\dagger}$

\begin{tabular}{cllllll} 
Type & & Semantic field & P.CL & Example N & Translation & Gloss \\
general 1 & any object, building, person... & anyin & tusi & 'his book' & GEN \\
\hline & 2 & food & an & koko & 'his yam' & FOOD \\
& 3 & drink & belen & köiö & 'his water' & DRI \\
& 4 & idea, thought & hnen & hnaûnykûme & 'his thought' & IDEA \\
S & 5 & noise, sound & hwan & hwahluma & 'his laugh' & SOU \\
p & 6 & wound, feeling; patient & hnâân & aat & 'his wound' & PAT \\
e & 7 & headdress & bicen & sei & 'her flower in her hair' & HEAD \\
c & 8 & catch, game & haniny & wââ & 'his fish' & CATC \\
i & 9 & pet & haaleeny & waau & 'his cat' & PET \\
f & 10 & plant, tree, root & noon & wahanic & 'his orange tree' & TREE \\
i & 11 & horizontal, flat area & iiny & hnyei & 'his field' & HORI \\
c & 12 & arrow, pike, sharp object & dâân & öö & 'his assegai' & SHAR \\
& 13 & basket, bag & tangen & tang & 'his basket' & BAG \\
& 14 & boat, craft & hoon & karopëë & 'his pirogue' & BOAT \\
& 15 & house, building & umwen & uma & 'his house' & HOUS \\
\hline & 16 & chewing food & hicen & waasu & 'his chewing-gum' & CHEW \\
U & 17 & portion of sugar cane & iien & aakû & 'his sugar cane' & CAN \\
n & 18 & "mana," strength & mënyin & mën & 'his strength' & MANA \\
i & 19 & burden, load & hönen & hook & 'his burden' & LOAD \\
q & 20 & net & ûten & eet & 'his net' & NET \\
u & 21 & heating fire & hlogon & meic & 'his fire' & FIRE \\
e & 22 & path, road & deeny & gethen & 'his path' & ROAD \\
& 23 & reef & waiicin & wai & 'his reef' & REEF \\
\hline
\end{tabular}

After Ozanne-Rivierre (1976:188-94).

$+\quad$ Ozanne-Rivierre gives for iiny the following semantic content (my translation): "dependant possessive auxiliary used to mark possession of a land: field, island, mat and different items produced by someone" (1976:190). I generalized, considering that it is used for all flat and horizontal surfaces or things spread on the floor.

2.2.1 General classifier. The general classifier anyin is semantically neutral and can occur with any noun without referring to a particular kind of possessive relationship, as illustrated in examples below, involving nouns referring to an animate (3a), inanimate (3b) and (3c) (Ozanne-Rivierre 1976:190), or including a neologism by loan (3c). ${ }^{15}$
(3) a. anyi-k
than P.CL_GEN-POS.1SG chief 'my chief'
b. anyi-k P.CL GEN-POS.1SG fish 'my fish trap'

The general classifier applies to any free noun, either concrete or abstract. ${ }^{16}$ It heads an open paradigm of nouns and performs a double function: on the one hand, it is a "complement classifier" (according to Zubin and Shimojo 1993), attested with nouns excluded by the nominal categories of the other classifiers - nouns in the examples in (3) above are

15. The origin of lexical borrowings is specified in the examples by the abbreviation of the source language in the exponent: ${ }^{\text {Eng }}<$ English; ${ }^{\mathrm{Fr}}<$ French.

16. Examples of anyin with abstract nouns: anyin môk 'his/her death', anyin ûsab̂े 'his/her conversation' (Ozanne-Rivierre 1984:87; 119). 
exclusively attested with anyin) — whereas, on the other hand, it is also a "default classifier" (Zubin and Shimojo 1993) when the semantic specification granted by a more precise classifier is not required by the speaker or the context (see Ozanne-Rivierre 1976:188-89). Contrast (4a) and (4b) below, where the general classifier is preferred when talking about a possessed 'mango' for which the function is not necessarily obvious (for example: an item to be sold, or a fruit the possessor just gathered):
(4)
a. bele-n
o-mââng ${ }^{\mathrm{Fr}}$
P.CL_DRI-POS.3SG small.mango
b. anyi-n
o-mââng ${ }^{\mathrm{Fr}}$ P.CL_GEN-POS.3SG small.mango 'his mango (to suck; ripe mango)' 'his mango (general property)'

2.2.2 Specific classifiers. Fourteen Iaai classifiers are identified as specific (see table 1 above), meaning that they can be used with a large category of nouns corresponding to the same semantic field..$^{17}$ This is illustrated in the following examples with belen, ${ }^{18}$ the classifier used to mark the possession of all drinkable substances:
(5)
a. bele-n
trii Eng
P.CL_DRI-POS.3SG tea
'his tea (to drink)'
b. beli-k waajem
P.CL_DRI-POS.1SG watermelon
'my watermelon (to drink)'

Specific classifiers are used with open paradigms of nouns that easily integrate neologisms, including loan words, as shown in example (5a) with the noun trii 'tea', borrowed from English.

2.2.3 Unique classifiers. Finally, eight classifiers are unique, meaning that they can only be used with one particular noun that constitutes its own paradigm. The examples given in the last section of table 1 constitute the only possible combinations between these unique classifiers and their attributed nouns. Examples (6) and (7) below illustrate unique classifiers in Iaai:

(6)
a. iie-n
aakû
P.CL_CAN-POS.3SG sugar_cane
'his sugar-cane (to masticate)'
b. *iie-n waasu
P.CL_CAN-POS.3SG chewing-gum

Intended: 'his chewing-gum (to masticate)'

17. To answer to one concern of a reviewer, it is difficult to decide if these specific classifiers relate to a functional usage based on semantics or if they represent inherent characteristics of the possessed noun as well, because one option does not exclude the other. For example, the classifier dâân used to mark possession of nouns referring to assegais, pikes, or weapons clearly comes from the verb döö 'to prick' and is based on the functional usage of these objects, used to prick objects, food, plants, or animals. But it does also suggest that the referent object has the inherent characteristics allowing pricking: a sharp object or something provided with a point or a tip.

18. Nouns receiving a possessive suffix can undergo vocalic alternations that respect relatively regular and predicable changes, as given in Lynch, Ross, and Crowley (2002:782). 
Unique classifiers often relate to a sharp semantic specialization. This may relate to particularly prominent cultural themes for the community (see Grinevald [2004:1017] for the example of 'dog' in Jakaltek). The grammaticalized distinction by a unique classifier highlights a cultural motivation in that speakers "choose" to emphasize a special noun or item by distinguishing it with a proper possessive classifier. For instance, sugarcane, very commonly cultivated and eaten in Ouvéa (Izoulet 2005:45), has its own unique classifier in Iaai, iien, ${ }^{19}$ which differs from the ones used with other kinds of food. ${ }^{20}$ The need for specialized language in order to categorize (by a different classifier) special nouns according to particular functions puts a stress on categories of cultural significance (see Lakoff 1986; Grinevald 2015).

Unlike certain Micronesian languages, unique classifiers in Iaai are not exclusively repeaters. In fact, there are only three unique classifiers given by Ozanne-Rivierre that are repeaters (mëniny “'mana," strength'; honen 'burden, load'; and waiicin 'reef'; see table 1 for examples). However, repeaters are found among specific classifiers in Iaai (tangen tang 'his basket'; umwen uma 'his house'; hoon hu 'his boat'; noon nu 'his coconut tree'; and so on).

2.3 FLUIDITY OF THE SYSTEM AND VARIATION. There is another characteristic of the Iaai system that is relevant to this study, that Lichtenberk (2009) calls "fluidity": the possibility for some nouns to be used with different classifiers depending on the possessive relation expressed. ${ }^{21}$ Fluidity is very common in Oceanic languages that have classifiers and this is illustrated in Iaai by the following examples:

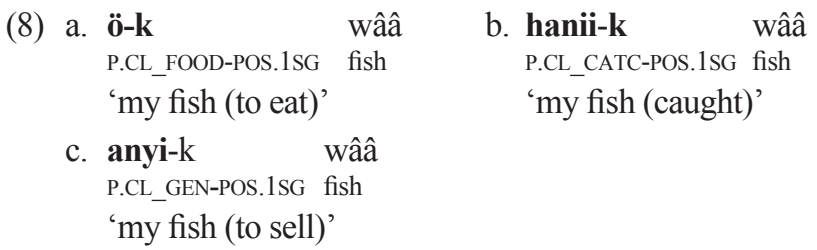

Accordingly, fluidity highlights the fact that such systems of classifiers have a strong pragmatic-discursive dependence (Grinevald 2002; Grinevald and Seifart 2004). That is to say, the choice between one classifier and another is prescribed by the context of speech (discursive) and by the intention of the speaker (pragmatic), which highlights the nature of the relationship between the possessed item and its possessor: does the speaker,

19. In her grammar, Ozanne-Rivierre (1976:190) notes iien, with a long initial vowel, whereas in her dictionary (1984:69) she gives ien, with a short initial vowel. According to my recordings, it seems to me that a long initial vowel is more frequent.

20. This is common to Kanak languages that display possessive classifiers to distinguish sugarcane, or food you have to masticate by pulling the fiber, from nouns referring to other kinds of food by using distinct possessive classifiers. What is striking, in fact, is that, in Iaai, in addition to this unique classifier for sugar-cane, there is another unique classifier used for chewing-gum: hicen waasu 'his chewing-gum'. Traditionally, waasu designated a kind of bark to chew (from the banyan tree) and has been then extended by metaphor to the chewing-gum introduced by the Americans during the Second World War.

21. According to Ozanne-Rivierre (1976:159), some free nouns in Iaai can be used as bound nouns as well, depending on the nature of the relation with the possessor. She gives the example of (i) free noun in indirect possessive construction: anyin jöö 'his bone' (for a dog playing with a bone) versus (ii) bound noun in direct possessive construction jeien 'his bone' (of his anatomy). 
in a particular speech situation, want to emphasize this relationship by using a specific or unique classifier, or does he want to avoid indicating a relationship? This choice is reinforced by the existence of the general and semantically neutral anyin that can substitute for any other classifiers when specification is neither desired by the speaker nor required from the context of utterance. This substitution can also occur under certain developmental (first language acquisition among children, cf. Erbaugh 1986) and sociolinguistic conditions (variation of language registers). As will be seen in 4.2, the growing usage of the general classifier is also viewed as a symptom of attrition in a language.

\subsection{THE IAAI INVENTORY IN A COMPARATIVE PERSPECTIVE.}

Iaai's possessive classifier system is a particularly outstanding system from an areal comparative perspective. With regard to number alone, with over twenty possessive classifiers, Iaai contains more than twice the number as compared with most other Kanak languages (containing an average of six classifiers). Nêlêmwa, which ranks second among Kanak languages in terms of the size of the classifier system, contains a dozenbetween ten and thirteen, according to Bril (2002:364-67, 2013).

Among the Oceanic languages that distinguish between direct and indirect possessive constructions, the widest semantic spread of a classifier is limited to a binary distinction between a general class and a consumable class including both food and drink. This is true, for example, with Manam from Papua New Guinea (Lichtenberk 1985:105). As I mentioned above, POC has been reconstructed with a system of three possessive classifiers (general / foods / drinks), and similar patterns are found today in, for example, Fijian. In addition to the POC inherited set, Iaai displays semantic categories that are commonly shared in languages displaying a large inventory of classifiers: one dedicated to 'house and building'; one for 'boat and vehicles', and one for 'pets and valuable things'22 (Blust 2009:487; Carlson and Payne 1989). Micronesian languages are known for having the largest paradigms of possessive classifiers, and table 2 illustrates the five shared semantic fields of classifiers between four of these languages and Iaai.

In addition to these five more common semantic fields, Iaai is distinguished from the other languages discussed in Carlson and Payne's study by having eleven more semantic

\section{TABLE 2. COMMON SEMANTIC FIELDS OF IAAI POSSESSIVE CLASSIFIERS COMPARED WITH FOUR MICRONESIAN LANGUAGES ${ }^{\dagger}$}

\begin{tabular}{llllll}
$\begin{array}{l}\text { Semantic fields } \\
\text { General }\end{array}$ & $\begin{array}{l}\text { Iaai } \\
\text { anyi- }\end{array}$ & $\begin{array}{l}\text { Marshallese } \\
\text { haha- }\end{array}$ & $\begin{array}{l}\text { Woleaian } \\
\text { yaa- }\end{array}$ & $\begin{array}{l}\text { Mokilese } \\
\text { a- }\end{array}$ & $\begin{array}{l}\text { Pohnpeian } \\
\text { aa- }\end{array}$ \\
$\begin{array}{l}\text { Food } \\
\text { kijë- }\end{array}$ & gela- & kara- & kene- \\
Drink & bele- & limë- & ûlûmë- & nima- & nime- \\
Boat & hoo- & walë- & waa- & wara- & were- \\
$\begin{array}{l}\text { House } \\
\text { Pet } / \text { valuable } \\
\text { things }\end{array}$ & umwe- & yimë- & imwe- & imwa- & imwe- \\
\hline
\end{tabular}

† Adapted version of Carlson and Payne (1989:95).

22. An anonymous reviewer rightly pointed out that it seems to be a general semantic tendency in Oceanic languages to distinguish one by one the possession of 'food'; 'drink'; 'house'; 'transport' or 'boat' and of 'valuable items'. What I wanted to highlight here is that languages distinguishing all these semantic categories at the same time are rare and, for the most part, from the Micronesian subgroup. 
fields. Among them, two characterize different modalities of food ingestion: hicen 'food to chew' and iien 'food to masticate'. This need to specify the mode of ingestion is widespread among Kanak languages, and most of these languages displaying classifiers in indirect possessive constructions actually demonstrate a larger set of classifiers related to food than does Iaai. Table 3 below illustrates this diversity of possessive expression for foods and drinks in the eight Kanak languages using classifiers for indirect possessive constructions. ${ }^{23}$ It should be noted that Iaai is the only language from the Loyalty Islands subgroup to make this semantic distinction.

In comparison with these other Kanak languages, Iaai displays fewer distinctions in the semantic fields of food and drink, demonstrating only four classifiers: the two previously cited ones, plus belen for 'drinks' and an for 'any kind of food'. Nêlêmwa, by contrast, shows a richer system with six different classifiers distinguishing food on the basis of its nature or the way of eating it (categorizing thus the possessee, following Aikhenvald 2013).

Another difference between Iaai and other Kanak languages is that Iaai is the only one that exhibits a general classifier (anyin), whereas the others, in the same context, use a relator, that is to say a functional marker without any possessive suffix (see Ozanne-Rivierre 1991). ${ }^{24}$

A larger comparative study of the Kanak languages is necessary to more fully understand the depth of their diverse possessive classifier systems. At present, however, the diversity of possessive classifiers systems in Oceanic languages can be represented on a continuum (figure 1) that begins with a minimal system that conserves an alienable/

\section{TABLE 3. POSSESSIVE CLASSIFIERS FOR FOOD AND DRINK IN EIGHT KANAK LANGUAGES ${ }^{\dagger}$}

\begin{tabular}{|c|c|c|c|c|c|c|c|c|}
\hline SUBGROUPS & & NORTH & ERN & & & SOUTHERN & & LOYALTY \\
\hline $\begin{array}{l}\text { Languages } \\
\text { Drink }\end{array}$ & $\begin{array}{l}\text { Nêlêmwa } \\
\text { kêâ- }\end{array}$ & $\begin{array}{l}\text { Nyelâyu } \\
\text { uduu- }\end{array}$ & $\begin{array}{l}\text { Bwatoo } \\
\text { bwidoo- }\end{array}$ & $\begin{array}{l}\text { Cèmuhî } \\
\text { idè- }\end{array}$ & $\begin{array}{l}\text { Tîrî } \\
\text { odho- }\end{array}$ & $\begin{array}{l}\text { Xârâcùù } \\
\text { (nê)wînyè- }\end{array}$ & Drubea & $\begin{array}{l}\text { Iaai } \\
\text { bele- }\end{array}$ \\
\hline Food (general) & & & & & & nênè- & nrètè- & a- \\
\hline $\begin{array}{l}\text { Portion of } \\
\text { starchy foods }\end{array}$ & caa- & yaa- & zha- & è- & e- & nèkê- & ngé- & \\
\hline $\begin{array}{l}\text { Portion of } \\
\text { protein }\end{array}$ & khoo- & wee- & xhua- & wiè- & hwee- & (nê)wînè- & pwè- & \\
\hline $\begin{array}{l}\text { Portion to } \\
\text { chew }\end{array}$ & maa- & mhaa- & fwaa- & & hwiie- & nèxwêê- & & hice- \\
\hline $\begin{array}{l}\text { Portion to } \\
\text { masticate }\end{array}$ & khora- & wha- & xhuta- & & & & kwè- & ie- \\
\hline $\begin{array}{l}\text { Portion of veg- } \\
\text { etables; fruits } \\
\text { or cooked } \\
\text { leaves }\end{array}$ & kûû- & ûû- & xu- & uu- & ere- & & & \\
\hline Portion of fish & & & & & & & té- & \\
\hline
\end{tabular}

$\bar{\dagger}$ Sources: Nêlêmwa (Bril 2002); Nyelâyu (Ozanne-Rivierre 1998); Bwatoo (Rivierre and Ehrhardt 2006); Tîrî (Osumi 1995); Xârâcùù (Moyse-Faurie 1995); Drubea (Paita and Shintani 1990); Cèmuhî (Rivierre 1980); Iaai (Ozanne-Rivierre 1976).

23. Semantic domains other than food and drink can also be encoded by additional possessive classifiers in the Kanak languages mentioned here.

24. As, for example, in Xârâcùù (Moyse-Faurie 1995:20): puunèmû rè wîrî 'your belts', where rè is a semantically neutral relator in an indirect possessive construction (puunèm $\hat{u}$ 'belt' and wir $\hat{\imath}$ ' $2 \mathrm{PL}$ ') that does not bear any person mark. 


\section{FIGURE 1. CONTINUUM OF POSSESSIVE CLASSIFIER SYSTEMS IN OCEANIC LANGUAGES}

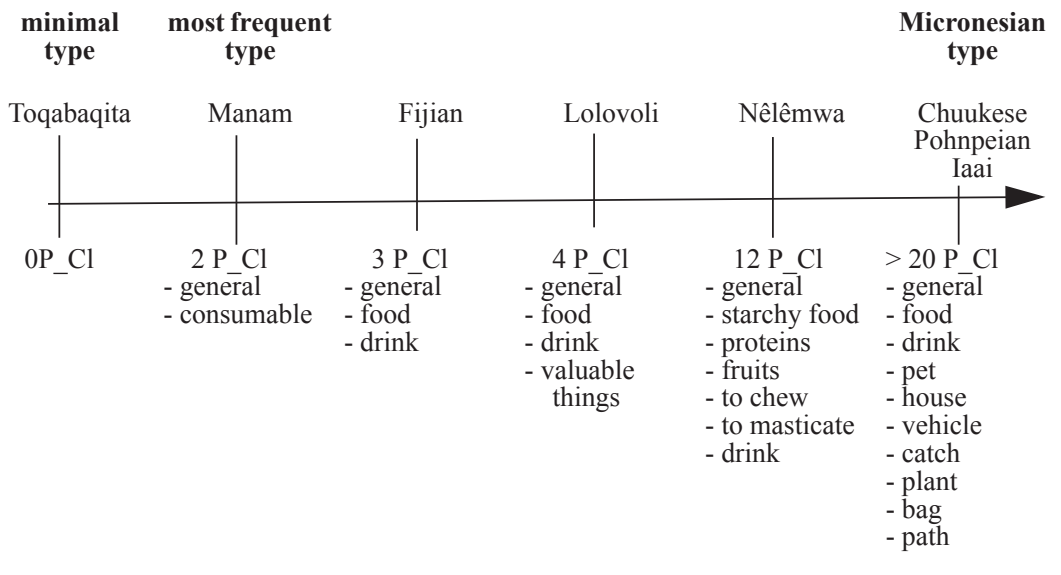

inalienable contrast in possessive construction $\mathrm{s}^{25}$ but is without classifiers; moves on to a binary system, as found in Manam and in the major part of the Oceanic languages; then to the POC tripartite system, encountered today in Fijian; and finally expands to reach complex systems, like those found in some Micronesian languages and in Iaai.

3. METHODOLOGY OF THE STUDY. The study that I conducted on possessive classifiers was part of my $\mathrm{PhD}$ thesis (Dotte 2013) that was aimed at investigating the changes attested in Iaai by comparing the present state of the language with the fortyyear-old grammar of Ozanne-Rivierre (1976). My possessive classifiers study was based on first-hand data collected during fieldwork conducted both in Ouvéa and Nouméa in 2012 using a visual stimuli elicitation kit. This methodology has been chosen for the numerous advantages it presented, namely (and according to Majid 2012):

- rapidity and efficiency in the recording of the targeted phenomena;

- practicality for first-hand data collection on fieldwork;

- suitability for cross-speaker comparison;

- preliminary kit constitution in the perspective of a cross-linguistic study among other related languages.

Moreover, considering the vast semantic domain covered by Iaai possessive classifiers, stimulus-based elicitation turned out to be the best methodology in order to capture the largest array of these classifiers in a time-limited fieldwork period.

\subsection{COMPOSITION OF THE ELICITATION KIT AND PROTOCOL.} The stimuli kit, made up of sixty-four cards, showed color pictures of items of everyday life (traditional and modern), such as animals, means of transportation, foods, drinks, and

25. For instance, in Toqabaqita, indirect possessive construction expresses inalienable possession by means of an independent pronoun rather than a possessive affix (Lichtenberk 1985:105, 2013:222). 
so on. ${ }^{26}$ These culturally relevant pictures were selected in order to minimize the interpretation effort from the informants (see figure 2 for an illustration.)

The elicitation kit targeted seventeen of the twenty-three possessive classifiers given by Ozanne-Rivierre (1976). It should be noted that not all of the semantic categories requiring a possessive classifier in Iaai were investigated in this study, due to iconographic-representation restrictions. This was the case, for instance, for hnen, the possessive classifier of 'thoughts, ideas'; and for mëniny, the classifier of "'mana," strength', neither easily represented in pictures.

Additionally, some pictures were added to the kit in order to test for classifiers that were not documented by Ozanne-Rivierre but were expected to exist. There were three expected classifiers: one related to 'seats' (based on Ray's 1926 description of the classifier taben); two related to 'necklaces/jewels' and 'dress/clothing' (based on a recent survey on the possessive classifiers inventories of some Micronesian languages). The elicitation kit created for this study included visual stimuli for these three additional domains. ${ }^{27}$

The protocol for conducting the test involved creating conditions of use for possessive classifiers in speech that was as natural as possible. For this purpose, speakers were asked to produce, for each card, a complete sentence naming both the object represented and the person to whom it supposedly belonged. Those supposed possessors, organized in a ran-

FIGURE 2. EXAMPLES OF STIMULI MAKING UP THE ELICITATION KIT ${ }^{\dagger}$

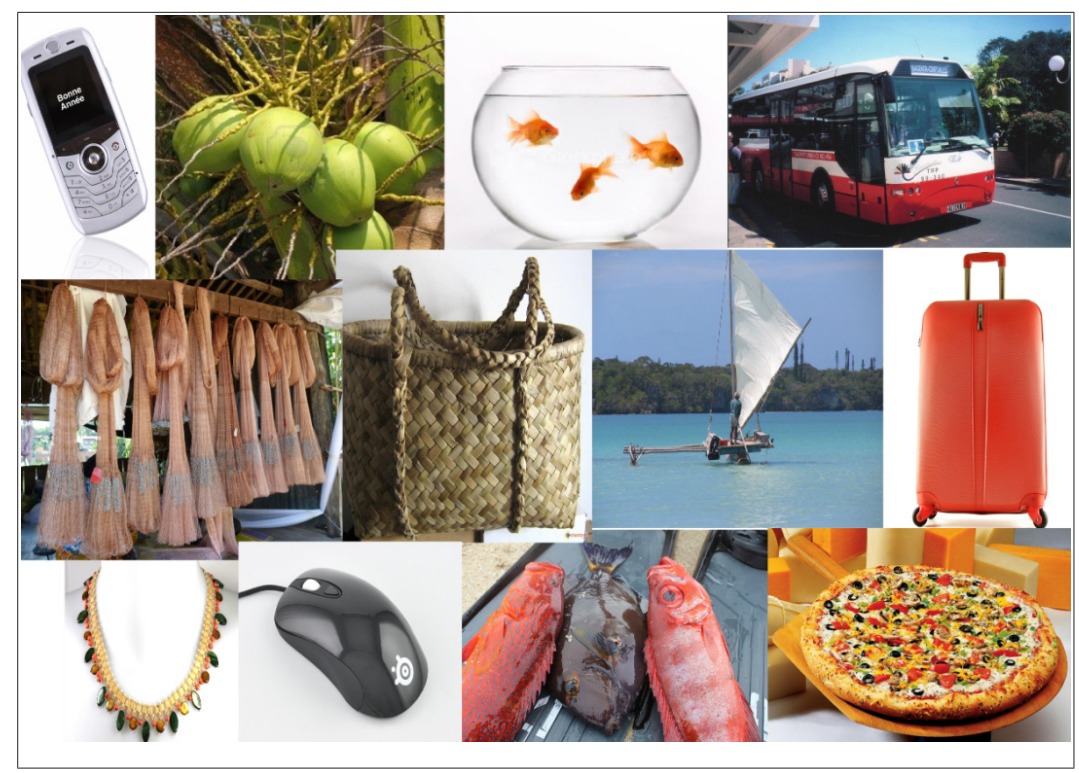

$\overline{\dagger \quad \text { (C) A-L. Dotte (2013). }}$

26. The whole kit is available on the TulQuest website at http://tulquest.huma-num.fr/fr/node/27.

27. Moreover, the elicited data obtained with the stimuli kit were complemented for this study with extra data from free narrations displaying occurrences of possessive constructions with classifiers - spontaneous conversations; oral story-tellings, and some stimuli-based narratives (see Dotte (2013:151-63). 
dom distribution, ${ }^{28}$ were either the speaker (1SG), myself as interlocutor (2SG), or a third party represented by a figure ( $3 \mathrm{SG}$ ). Each recording lasted approximately ten minutes.

3.2 INFORMANTS. While the stimuli kit and protocol were designed to elicit easily comparable data, the selection of informants allowed for analyses in both real- and apparent-time. In total, eighteen informants between 11 and 78 years of age were recorded. Eleven of them were less than 40 years old and considered "young speakers," whiles the other seven were considered "old speakers" (between 40 and 78 years old). Six of the participants were males and twelve were females. Two speakers were living in the urban context in Nouméa, but all of the others were inhabitants of various villages on the island of Ouvéa, where Iaai is traditionally spoken. Concerning general linguistic competency, all the informants were first-language speakers of Iaai bilingual in French, and some also have production and comprehension competencies in other Kanak languages (mostly West Uvean and Drehu). All participants were fluent Iaai speakers, however, of varying competence (cf. Dotte 2014).

The main purpose of the study was to compare speakers' possessive classifier repertoires ${ }^{29}$ and to identify sociolinguistic criteria (age; type of speaker; ${ }^{30}$ linguistic biography; etc.) that could explain any differences between them. Even though the sample size could be viewed as quantitatively restricted, the results were nonetheless revealing, and a clear measure of the relative obsolescence and resilience of the possessive classifier system in Iaai was demonstrated.

\subsection{A DOUBLE APPROACH FOR UNDERSTANDING LINGUISTIC}

CHANGE. The methodology of the present study borrows its theoretical framework from variationist sociolinguistics in that it considers how variation plays a crucial role in language change. Moreover, studying variations allows us not only to make the statement that a language change has occurred, but also (and above all) to observe the change in progress. In this goal, two complementary approaches can be combined: real-time and apparent-time (see Meyerhoff 2006:127-54; Sankoff 2005; Turell 2003).

In the present study, the real-time analysis compared the inventory given by OzanneRivierre in her grammar of Iaai (1976) with the results from the recent experiments, forty years later. The variations attested between these two corpora are taken to provide a diachronic picture of what changes have occurred over time.

The apparent-time analysis compared the set of individual repertoires from the different participants at the experiment driven in Nouméa and Ouvéa during fieldwork in 2012. It took into account extra-linguistic factors, such as age and language attitude. The variations found between the productions of young versus old speakers are assumed to provide insights into language change in a synchronic perspective.

28. The picture-cards were shuffled before each recording with different informants.

29. In this paper, I make a terminological distinction between inventory and repertoire. I use the term inventory of classifiers to refer to the whole list of classifiers attested in the language, whereas repertoire indicates the list of classifiers attested in the speech of a particular informant. The inventory of possessive classifiers in Iaai includes all the repertoires of such classifiers for every single Iaai speaker.

30. Considering the proposition of typology by Bert and Grinevald (2010), Grinevald and Bert (2011). 


\section{OBSOLESCENCE VS. RESILIENCE IN THE MODERN SYSTEM.}

The data collected via the stimuli kit provided new information for the Iaai possessive classifier system, which will be detailed in the following subsections. These phenomena can be distinguished on the basis of methodological criteria and different theoretical frameworks. First, the specific methodology employed permitted the identification of three classifiers not listed in Ozanne-Rivierre's (1976) inventory. As will be argued below, this should not be interpreted as a productive process in Iaai. Second, the comparative study between the system described by Ozanne-Rivierre and the present study revealed two "real-time" changes: (i) the loss of some classifiers and the consequent increased scope of the general classifier anyin; and (ii) the dynamism of resilience in the system evidenced by the incorporation of neologisms into the paradigms of classified nouns, as well as the semantic adaptation and metaphorical extension of taben to 'means of transportation'. Finally, the comparison between the repertoires of the different recorded informants demonstrates apparent-time shifts. This is related to the fact that the scope of individual repertoires depends on sociolinguistic factors and that the system could be obsolescing due to contact-induced change.

4.1 THREE ADDITIONAL CLASSIFIERS. Three additional classifiers were attested in the modern corpus and increase the previous list of classifiers known since Ozanne-Rivierre's grammar. These are: taben 'P.CL_seat'; xaaven 'P.CL_dress'; and kinyin 'P.CL_necklace' (see table 4). My hypothesis is that these three additional classifiers are not to be considered as "neoclassifiers," that is to say, new classifiers created to assume modern classificatory needs, but are rather classifiers that were not documented in previous descriptions.

There are three arguments in support of the hypothesis that these three classifiers are not recent innovations. First, the classifier taben was confirmed by Ray in his grammatical sketch (1926) but was absent from Ozanne-Rivierre (1976), fifty years later. This classifier is particularly interesting because of a semantic extension and will be discussed further in 4.4 .2 below.

Second, these additional classifiers have been attested in the individual repertoires of multiple speakers from different generations: seven speakers gave kinyin and taben and six speakers gave xaaven (see table 5). This varied and relatively wide distribution provides evidence against these three classifiers being nonce innovations by individual speakers.

\section{TABLE 4. ADDITIONAL POSSESSIVE CLASSIFIERS IN IAAI}

\begin{tabular}{|c|c|c|}
\hline CLASSIFIER & SEMANTIC FIELD & EXAMPLE FROM MODERN DATA \\
\hline taben & 'seats, transports' & $\begin{array}{l}\text { tabe-n } \\
\text { P.CL_SEAT-POS.3SG plane } \\
\text { 'his plane (seat; transport)" }\end{array}$ \\
\hline kinyin & 'necklaces' & $\begin{array}{ll}\text { kinyi-k } & \text { sawakiny } \\
\text { P.CL_NECK-POS.1SG necklace } \\
\text { 'my_necklace (necklace)' }\end{array}$ \\
\hline xaaven & 'dresses, clothes' & $\begin{array}{l}\text { xaavöö-k jee } \\
\text { P.CL DRES-POS.1SG ART.DEF.PL dress } \\
\text { 'my dresses (to wear)' }\end{array}$ \\
\hline
\end{tabular}


Third, xaaven 'clothes' and kinyin 'necklaces' emerged from modern data due to the very specific stimuli deliberately created to focus on semantic fields closely related to the target classifiers. As previously mentioned, their potential existence was hypothesized based on a brief comparative study of the semantics of possessive classifiers in some other Oceanic languages with a large inventory. For instance, Chuukese (Benton 1968:133-38, cited in Lichtenberk to appear) exhibits yacawara, a classifier for 'loincloth', as well as wiffa, a classifier for 'clothing worn on the torso'. The language also contains mwari, a classifier given for 'lei, encircling object'. A possessive classifier for 'thing to cover with' is also attested in Pohnpeian with ipe (Rehg and Sohl 1981:180) and in Mokilese with upah (Harrison 1976:130). Mokilese also exhibits a possessive classifier dedicated to necklaces: $m^{w}$ ara (Blust 2009:480). ${ }^{31}$

Given this observation, it can reasonably be hypothesized, then, that other possessive classifiers could exist in Iaai but, for whatever reason, went unnoticed in prior data collection. A strictly closed inventory is, thus, misleading and cannot be provided for Iaai.

4.2 CLASSIFIER LOSS. Some previously attested classifiers do not appear in the speech of contemporary Iaai speakers: ûten 'P.CL_net', dâân 'P.CL_sharp object', and waiiny 'P.CL_reef' ${ }^{32}$. None of the informants I recorded gave these classifiers for the corresponding stimuli. Instead, they were systematically substituted by anyin, the general classifier. At no time during any of my linguistic research with Iaai speakers did I witness use or knowledge of any of these three classifiers. It is, therefore, reasonable to argue that, at some point, cultural changes encouraged this obsolescence. This is perhaps more obvious for at least two of these lost classifiers, ûten and dâân, which were used in the context of traditional fishing techniques (by casting a net or by throwing a more traditional spear, respectively) that have been replaced by angling and spear-fishing. The loss of customary practices by the younger generation of Iaai speakers can, thus, be viewed as directly contributing to the erosion of these semantically restricted classifiers.

The massive generalization of anyin is a key characteristic of the dynamism of the Iaai possessive classifier system. It is clear from the present corpus that it has played, and continues to play, a prominent role in the strategy of forming indirect possessive constructions. Some speakers do not know or use the range of specification supplied by the richness of the system and, rather quasi-exclusively, employ the general classifier in every context (mainly, the youngest ones, see table 5 in 4.3). The neutralization of oppositions driven by the omnipresence of the general classifier within the individual repertoires induces a tendency to simplification and loss of diversity in the original system that can be regarded as linguistic obsolescence.

This phenomenon was previously reported in older descriptions of Iaai possession. Leenhardt noticed the generalization of the semantically neutral anyin and attributed this drastic change to formal education in Ouvéa and to the written translation of the Bible:

31. From a methodological perspective, these instances illustrate the benefit of pre-fieldwork regional and typological reviews in order to target the right domains of investigation. Other semantic domains could be tested in a future complementary study, based on some of the additional semantic domains attested in some Micronesian languages' possessive classifier systems.

32. Waiiny was not included in the stimuli kit considering that the three referring informants consulted prior to the elaboration of the kit did not accept its use as a classifier in possessive constructions. Instead, they use the general classifier: anyin waiin 'his reef'. 
... there would hence exist possessive categories. One of these categories has overcome the others. When one did not know which category to have recourse to, one employed the one that involved more especially the person, añi [anyi-], the property. The standardization of the language by the Bible translation, and school, contributed to accelerate this evolution. Añi tends to become the unique possessive expression (Leenhardt 1946:xxxviii). ${ }^{33}$

This quote from Leenhardt highlights two crucial points about the evolution of the classifier system. First, he describes two different kinds of evolution: (i) the general classifier anyin has served as a complement classifier in situations where no other category was available, for example, when classification has to do with a new object or notion; (ii) the acceleration of this change reveals that anyin serves as a default classifier in that it replaces classifiers that are semantically more precise. For Leenhardt, the general classifier absorbs innovations into an encompassing semantically neutral superclass, but, at the same time, infringes upon the categorized domains by the neutralization of its semantic specificities.

Second, the causes to which Leenhardt assigns this evolution implicate the standardization of Iaai by missionaries and Protestant teachers through two major projects: the translation of the Bible, which came with written codification of this oral traditional language; and formal education of children in indigenous schools. These two reasons are maybe not the only ones to have had an impact in the spread of the general classifier, but, for Leenhardt, the obsolescence of the possessive classifier system can be attributed to the language's normalization process.

Thirty years later, when Ozanne-Rivierre published her grammar of Iaai (1976), she noticed a similar phenomenon and pointed out that younger speakers tended to utilize the general classifier more than older speakers, who maintained the use of other classifiers. Among younger speakers, some individual repertories at the time appeared to completely do away with the specific or unique classifiers that Ray reported fifty years earlier (1926):

The bound noun ani- $k$ 'thing belonging to me', which marks a very general possession, tends to compete more and more with specific possessive forms of which some are not known anymore by the youth.

According to S. H. Ray (1926:94), possession for net was marked: ütə-keet 'my net', a form that is admitted by older informants, but unknown to young speakers who give ani-k eet 'my net', namely the more general possessive marker (Ozanne-Rivierre 1976:189). ${ }^{34}$

33. In the original: “On aurait ainsi des catégories possessives. Mais l'une de ces catégories l'a emporté sur les autres. Lorsqu'on ne savait à quelle catégorie recourir, l'on employait celle qui impliquait au plus haut point la personne, añi [anyi], le bien propre. La fixation de la langue par la traduction de la Bible, et l'école, ont contribué à précipiter cette évolution. $A \tilde{n} i$ tend à devenir l'expression possessive unique (Leenhardt 1946:xxxviii)."

34. In the original: "le nom dépendant $a n i-k$ 'chose à moi', qui marque une possession très générale, tend de plus en plus à concurrencer les formes possessives spécifiques dont certaines ne sont plus connues des jeunes. Selon S. H. Ray (1926, p. 94), la possession du filet se marquait: ütə- $k$ eet 'mon filet' forme admise par des informateurs âgés, mais inconnue des jeunes qui donnent: ani-k 'mon filet', c'est-à-dire la marque de possession la plus générale." 
Today, forty years after Ozanne-Rivierre's work, it is clear that the context of language contact and multilingualism in which Iaai speakers are involved probably plays a role in the linguistic changes attested and in the attrition of the classifier system. French, in which all the speakers are fluent bi/multilinguals and in which they are educated, does not express possession by means of indirect constructions involving classifiers but rather uses a unique possessive pronoun mon 'POS.1SG.MASC' / ma 'POS.1SG.FEM', varying according to gender of the possessed noun (related to sex for animate but not semantically motivated for inanimate) and person of the possessor. The tendency to use a general classifier in Iaai can, therefore, be reinforced because of the ecology of the language and can be interpreted as a contact-induced change (see Aikhenvald 2000:382-91 on "languageexternal motivations on the development and decay of noun categorization").

Based on the previous descriptions of these classifiers and an understanding of the sociolinguistic influence of non-Iaai speaking cultures, it becomes evident that the replacement of many possessive classifiers by the general classifier is not a recent event, and, in fact, is an ongoing phenomenon that pushes major elements of the possessive classifier system into obsolescence.

4.3 SCOPE OF INDIVIDUAL REPERTOIRES. The method of elicitation by visual stimuli enabled the discovery of individual classifier repertoires for each participant. These repertoires are significant both in terms of the total number of different classifiers each informant used during the test, and the variety of categories of classifiers each participant knows. The results are summarized in figure 3 and commented on below.

The data reveal that the majority of the classifiers already attested in previous studies have persisted and are used by most contemporaneous speakers. Only the two classifiers for 'sharp objects' (dâân) and for 'nets' (uten) were totally absent from the modern data.

\section{FIGURE 3. FREQUENCY OF POSSESSIVE CLASSIFIERS IN INFORMAL REPERTOIRES FROM ELICITATION STIMULI}

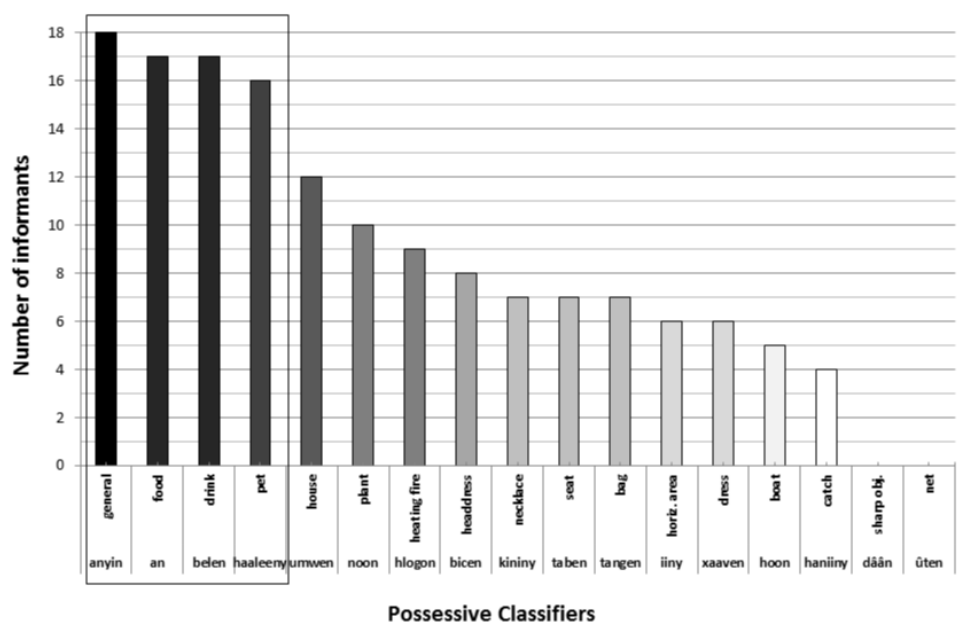


On the contrary, anyin, the general classifier, is the only classifier that was present in every single one of the eighteen individual repertoires. For one young boy, it was exclusively used for all elicited domains. This case supports the statement that, specifically in contexts of endangered languages, young speakers tend to have reduced use and knowledge of classifiers: see examples in Minangkabau in Marnita (2016), or in Chinese in Erbaugh (1986). Two classifiers were attested in the repertoire of all other informants: an 'food' and belen 'drink'. The fourth most frequently used classifier in the repertoires was the classifier for pets, haaleeny.

The semantic values of these four classifiers (framed in figure 3 ) are obviously related to one's vital needs and direct daily environment. It constitutes what can be considered as a "minimal core system" of possessive classifiers in Iaai, and it corresponds, semantically, to the system reconstructed for POC. ${ }^{35}$ This can lead one to believe that, despite the shrinking of the system, the obligatory classifiers to remain (if all other classifiers are to be lost) are the prototypical ones, a core from which we can hypothesize that the highly creative system had spread.

Furthermore, these results can be compared depending on sociolinguistic criteria such as age, sex, linguistic biography, and so on. Table 5 shows the attested classifiers for each informant and gives information about sex and age.

Genre does not prove to be a meaningful criterion here and does not impact the composition of the inventories, ${ }^{36}$ just as level of French proficiency does not appear as a relevant language-external motivation, considering that all the interviewed speakers are bilingual in French and have been educated in this dominant language. On the contrary, the apparent-time study reveals a strong age constraint on the scope and content of possessive classifier repertoires (cf. figure 1 in Meyerhoff to appear). Apart from some isolated cases that will be discussed further, the older the speaker, the more likely s/he is to show a large array of semantically distinct classifiers. This age constraint is an indicator of obsolescence of the system and of decrease of its diversity. Data from younger informants (under 15 years old) are quite homogeneous, indicating a small group of four to five identical classifiers. As previously mentioned, the youngest informant of the cohort employed only one classifier, the general one, for all semantic domains. Considering the apparent-time theoretical assumption, "if younger speakers behave differently from older speakers, it is assumed that change has taken place within the community" (Meyerhoff 2006:127), this variation in the scope of classifier repertoires is to be interpreted as a mirror image of ongoing language change.

Nevertheless, it cannot be ignored that nominal classification systems are liable to be progressively acquired, lifelong systems because they echo personal experiences, competences, and activities (cf. Erbaugh 1986). We must remain cautious of the interpretation of the younger speakers' results of this test because they are still learners of the language. On that topic, Rehg wonders "how, when we are trying to assess the vitality of a language, do we distinguish late acquisition from language attrition?' (1998:328). Individual classifier repertoires have to be considered as variable and dynamic systems per se, and this suggests that the apparent-time study must be understood as documenting a tendency more

$\overline{35 .}$. Plus the classifier for pet (semantically close to the one for valuable things in many other Oceanic languages).

36. Average number of classifiers for males: 8.16 ; average number for females: 8.3. 


\section{TABLE 5. IAAI POSSESSIVE CLASSIFIERS FOR EACH INFORMANT FROM STIMULI ELICITATION}

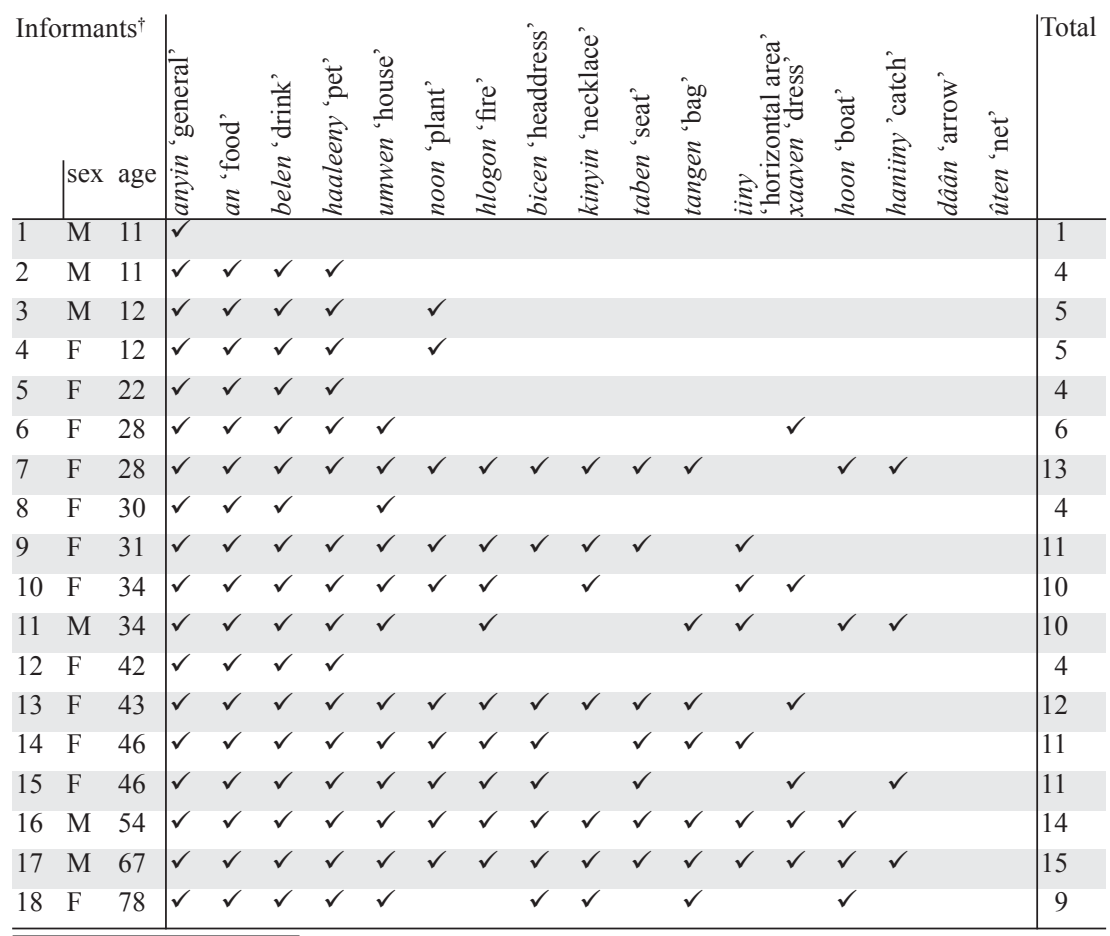

$\dagger \quad$ Informants have been numbered in this table to respect anonymity and for ease of reference.

than an absolute statement. An extended study on a larger cohort or a longitudinal study would be possible solutions to avoid this bias.

Other extra-linguistic criteria are relevant to explain speaker individual repertoire as linguistic biography, sociolinguistic attitude, and type of speaker. It emerges that the more the informants are involved in the promotion or teaching of the language, the more they conserve the semantic specifications of classifiers and the less they resort to the general. For instance, one young informant (28 years old, informant no. 7 in table 5), who displayed one of the larger repertoires of possessive classifiers (x13), was actually a language activist in the community and active in language conservation. Such conservative speakers are more inclined to make the most of the large range of classifiers of their language by preferring the integration of neologisms in the paradigm of specific classifiers rather than the generalized usage of anyin, and by welcoming semantic extension (as discussed for taben below) in order to categorize new items or activities.

Other age-related exceptions shown in table 5 can be justified by linguistic biography and type of speaker (informant no. 8, a young semi-speaker who lived for years in Nouméa city) and by the constraints of the methodology (as informant no. 18, an old woman who appeared to have difficulty distinguishing between the stimuli pictures). 
4.4 ADAPTATIONS IN THE SYSTEM. A tendency towards obsolescence is clearly occurring in the current Iaai system of possessive classifiers. However, a parallel dynamic of resilience can also be observed. The system shows a capacity to adapt when existing classifiers open their category to new paradigms of nouns referring to new activities or items, or when they are semantically extended to cover new meanings.

4.4.1 Incorporation of neologisms. Many examples in the corpus attest to the use of existing classifiers to encode indirect possession of coined nouns - either loans or the results of other kinds of word creation. The examples below illustrate this for different classifiers: with loan words from English (9), ${ }^{37}$ from French (10), ${ }^{38}$ and with a semantic calque (11).

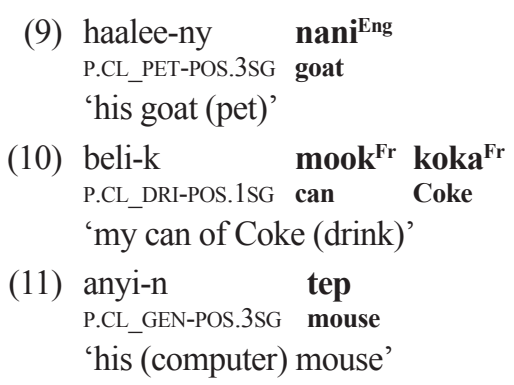

By definition, incorporation of neologisms is only possible in the paradigm of nouns of general and specific classifiers (and impossible in those of unique classifiers). This incorporation of neologisms is an argument in favor of the productivity of the system and of the flexibility of its nominal categorization.

4.4.2 Semantic extension. Apart from the ability to integrate new words in the nominal category, the resilience of the system is demonstrated through the semantic extension of one classifier. Originally, the possessive classifier taben was used for 'seats', as illustrated in examples below with the Iaai noun tap/untap 'chair/bench' (12a) or with the English loan cea from chair (12b).
a. tabe-n uutap P.CL_SEAT-POS.3SG chair 'his chair (to sit in)'
b. cea ${ }^{\text {Eng }}$ tabe-n in 'the girl's chair (to sit in)' chair P.CL_SEAT-POS.3SG girl

However, in the modern data, it is attested in the repertoires of six of the eighteen informants with nouns referring to means of transportation. By visual analogy in relation to the traveler, this rather semantically restricted classifier has become the one for car; bus; bicycle; airplane - in fact, any form of transport in which you are seated (as in examples $(13 \mathrm{a}, \mathrm{b})$, and was even used as a replacement of the dedicated classifier for boats, hoon $(13 \mathrm{c})$.

$$
\begin{array}{ll}
\text { (13) a. } & \text { tabâ-m } \\
& \text { P.CL_SEAT-POS.2SG } \text { bar }^{\mathrm{Fr}} \\
& \text { 'your bus (transport)' }
\end{array}
$$
b. tabö-k aviậ ${ }^{\mathrm{Fr}}$ P.CL_SEAT-POS.1SG plane 'my plane (transport)'




\section{c. tabö-k hu \\ P.CL_SEAT-POS.1SG boat \\ 'my boat (transport)'}

5. SUMMARY AND CONCLUSIONS. This paper investigated the dynamics and changes occurring in the possessive classifier system of modern Iaai. The convergence of Iaai linguistic ecology and the inherent characteristics of its classifier system have led to a variable system. The heavy linguistic contact and dominance of French, together with Iaai's subsequent endangerment, have caused changes in some areas of this indigenous language's structure and function. At the same time, classifier systems are known to be moving both diachronically and synchronically. The highly dynamic character of the possessive classifier system in Iaai is further accentuated by the fact that it is very open, and it is widely accepted that such systems are intrinsically subject to internal variation.

The recent data presented in this study have shown that the system given by OzanneRivierre (1976) has changed. First, at least three classifiers were absent in her grammar. These classifiers (kinyin 'P.CL_necklace', taben 'P.CL_seat', and xaaven 'P.CL_dress') have been recovered, so to speak, through stimuli elicitation. This recovery demonstrates the importance of methodological advances in data collection and the benefits of continued typological-areal comparative studies.

Second, concerning linguistic change, two main tendencies were discussed: loss versus resilience. On one hand, three classifiers have become obsolete in today's Iaai: ûten 'P.CL_net', dâân 'P.CL_sharp object', and waiiny 'P.CL_reef'. They have all been replaced by the use of the semantically neutral classifier anyin. This general classifier has gained in extension and in frequency and is substituting for other, more semantically precise classifiers. It is attested with numerous neologisms and is sometimes exclusively employed in indirect possessive constructions, excluding, remarkably, its role of "classifying" the noun or the nature of the relation between the possessor and the possessed item. The identification of obsolete classifiers and the expansion of the general one are simplifications of the system and, therefore, evidence of linguistic obsolescence. It also appears clear that the scope of the possessive classifier system depends on sociolinguistic criteria such as age, a speaker's linguistic biography, and their personal involvement in language activism. This was shown in that older speakers, and speakers playing active roles in the maintenance of the language, displayed a larger array of classifiers in their repertoires.

On the other hand, the dynamic of change also indicates a sort of linguistic resilience. Neologisms, whether they are loans or the results of other kinds of word creation, are coherently incorporated within the paradigm of classified nouns of preexisting classifiers. They integrate into either a specific classifier's paradigm, in accordance with the semantic field covered, or the paradigm of the general classifier. Adaptation in the system is also demonstrated in the semantic enlargement of a preexisting classifier. To restate the example, taben, which was originally employed to encode possession of items to sit on, now extends to mark the possession of any means of transportation: bus, car, bicycle, airplane, and so on.

Finally, this study has led to the proposal of a new inventory of possessive classifiers for the modern Iaai language, one that takes into account the dynamics and changes dis- 
cussed above. Table 6 regroups the classifiers identified in decreasing order of frequency in the informants' repertoires.

It is important to note that the core of the most frequently shared classifiers between informants is made up of the three classifiers that are semantically identical to the POC system. It can be reasonably argued that the inherited set from which the diversification of the Iaai system had then flourished still constitutes the basic core of a nonreducible system attested for most Iaai speakers today. It is striking to note that in Iaai, as in many Micronesian languages, the original three-classifiers set expanded from POC to a larger inventory. This paper has also shown that several semantic domains encoded by possessive classifiers in Iaai are similar to those in some Micronesian languages. This raises the question: at what stage in the history of the Oceanic languages did this diversification occur?

In sum, this paper not only sheds light on the threat to the extraordinary richness of the Iaai possessive classifier system, but also offers insight into the natural and spontaneous ability of Iaai to create and adapt to new linguistic ecology and needs. Linguistic resilience is, in this sense, a notion to explore and to refer to in the purpose of supporting "speakers' creative performance" and "remarkable survival and adaptability" (Makihara 2001) of languages in a minority context.

\section{TABLE 6. MODERN INVENTORY OF CLASSIFIERS IN IAAI}

\begin{tabular}{|c|c|c|c|c|c|c|}
\hline 1 & $\begin{array}{l}\text { Semantic field } \\
\text { any object, building, } \\
\text { person... }\end{array}$ & $\begin{array}{l}\text { P.CL_- } \\
\text { anyin }\end{array}$ & $\begin{array}{l}\text { Example } \mathbf{N} \\
\text { tusi }\end{array}$ & $\begin{array}{l}\text { Translation } \\
\text { 'his book' }\end{array}$ & $\begin{array}{l}\text { Gloss } \\
\text { GEN }\end{array}$ & \multirow{4}{*}{ core } \\
\hline 2 & food & an & koko & 'his yam (to eat)' & FOOD & \\
\hline 3 & drink & belen & köiö & 'his water (to drink)' & DRI & \\
\hline 4 & pet & haaleeny & waau & 'his cat' & PET & \\
\hline 5 & house, building & umwen & uma & 'his house' & HOUS & \multirow{3}{*}{ common } \\
\hline 6 & plant, tree, root & noon & wahanic & 'his orange tree' & TREE & \\
\hline 7 & heating fire & hlogon & meic & 'his fire' & FIRE & \\
\hline 8 & headdress & bicen & sei & 'her flower in her hair' & HEAD & \multirow{8}{*}{ uncommon } \\
\hline 9 & necklace & kinyin & sawakiny & 'his necklace' & NECK & \\
\hline 10 & seat; transport & taben & loto & 'his car' & SEAT & \\
\hline 11 & basket, bag & tangen & tang & 'his basket' & BAG & \\
\hline 12 & horizontal, flat area & iiny & hnyei & 'his field' & HORI & \\
\hline 13 & dress, clothing & xaaven & ûxaaû & 'her dress' & DRES & \\
\hline 14 & boat, craft & hoon & karopëë & 'his pirogue' & BOAT & \\
\hline 15 & catch, game & haniiny & wââ & 'his fish (caught)' & CATC & \\
\hline 16 & idea, thought & hnen & hnaûnykûme & 'his thought' & IDEA & \multirow{8}{*}{ rare } \\
\hline 17 & path, road & deeny & gethen & 'his path' & ROAD & \\
\hline 18 & chewing food & hicen & waasu & 'his chewing-gum' & CHEW & \\
\hline 19 & $\begin{array}{l}\text { wound, feeling; } \\
\text { patient }\end{array}$ & hnâân & aat & 'his wound' & PAT & \\
\hline 20 & noise, sound & hwan & hwahluma & 'his laugh' & SOU & \\
\hline 21 & "mana", strength & mënyin & mën & 'his strength' & MANA & \\
\hline 22 & portion of sugar cane & iien & aakû & 'his sugar cane' & CAN & \\
\hline 23 & burden, load & hönen & hook & 'his burden' & LOAD & \\
\hline
\end{tabular}




\section{REFERENCES}

Aikhenvald, Alexandra Y. 2000. Classifiers: A typology of noun categorization devices. Oxford: Oxford University Press.

- 2013. Possession and ownership: A cross-linguistic perspective. In Possession and ownership: A cross-linguistic typology, ed. by Alexandra Y. Aikhenvald and R. M. W. Dixon, 1-54. Oxford: Oxford University Press.

Barnèche, Sophie. 2005. Gens de Nouméa, gens des îles, gens d'ailleurs... Langues et identités en Nouvelle-Calédonie. Paris: L'Harmattan.

Benton, Richard. 1968. Numeral and attributive classifiers in Trukese. Oceanic Linguistics 7:104-46.

Bert, Michel, and Colette Grinevald. 2010. Proposition de typologie des locuteurs de LED. Faits des Langues / Linguistique de terrain sur langues en danger: locuteurs et linguistes 35-36:117-32.

Blust, Robert. 2009. The Austronesian languages. Canberra: Pacific Linguistics.

Bril, Isabelle. 2002. Le nêlêmwa, Nouvelle-Calédonie: Analyse syntaxique et sémantique. Paris: Peeters.

- 2013. Ownership, part-whole and other possessive-associative relations in Nêlêmwa (New Caledonia). In Possession and ownership: A cross-linguistic typology, ed. by Alexandra Y. Aikhenvald and R. M. W. Dixon, 65-89. Oxford: Oxford University Press.

Carlson, Robert, and Doris Payne. 1989. Genitive classifiers. In Proceedings of the Fourth Annual Pacific Linguistics Conference, ed. by Robert Carlson, Scott DeLancey, Spike Gildea, Doris Payne, and Anju Saxena, 87-119. Eugene: University of Oregon.

Colombel, Claire, and Véronique Fillol. 2012. Enjeux des langues d'enseignement dans la construction de l'identité scolaire des jeunes océaniens francophones. In La construction identitaire à l'école: Perspectives linguistiques et pluriculturelles, ed. by Françoise Demougin and Jérémi Sauvage, 113-20. Paris: L'Harmattan.

Craig, Colette. 1986. Jacaltec noun classifiers: A study in language and culture. In Noun classes and categorization, ed. by Colette Craig, 263-93. Amsterdam: John Benjamins.

Dotte, Anne-Laure. 2013. Le iaai aujourd'hui: Évolutions sociolinguistiques et linguistiques d'une langue kanak de Nouvelle-Calédonie (Ouvéa, Îles Loyauté). PhD thesis, Université Lumière-Lyon 2.

. 2014. Silences et paroles sur le terrain: Ce que la diversité des locuteurs nous dit de la vitalité du iaai (Ouvéa, Iles Loyauté, Nouvelle-Calédonie). In Terrains océaniens: Enjeux et méthodes, ed. by Véronique Fillol and Pierre-Yves Le Meur, 341-57. Paris: L'Harmattan.

Erbaugh, Mary. 1986. Taking stock: The development of Chinese noun classifiers historically and in young children. In Noun classes and categorization, ed. by Colette Craig, 399-436. Amsterdam: John Benjamins.

François, Alexandre. 1999. L'illusion des classificateurs. Faits des Langues / La catégorisation dans les langues 14: 166-76.

Franjieh, Michael. 2012. Possessive classifiers in North Ambrym, a language of Vanuatu: Explorations in semantic classification. PhD Thesis. SOAS, University of London.

Franjieh, Michael, and Kilu von Prince. 2011. Classifying nouns vs. classifying relations: A case study from Ambrym. Proceedings of Conference on Language Documentation and Linguistic Theory 3, ed. by Peter Austin, Oliver Bond, Nathan David, and Lutz Marten, 111-19. London: SOAS. 
Geraghty, Paul. 1983. The history of the Fijian languages. Honolulu: University of Hawai'i Press.

Grinevald, Colette. 2000. A morphosyntactic typology of classifiers. In Nominal classification, ed. by Gunter Senft, 50-92. Cambridge: Cambridge University Press.

- 2002. Making sense of nominal classification systems: Noun classifiers and the grammaticalization variable. In New reflections on grammaticalization, ed. by Gabriele Diewald, and Ilse Wischer, 259-75. Amsterdam: John Benjamins.

- 2004. Classifiers. In Morphology, ed. by Geert Booij, Christian Lehmann, Joachim Mugdan, and Stavros Skopeteas (in collaboration with Wolfgang Kesselheim), 1016-31. Berlin: Mouton De Gruyter.

- 2015. Linguistics of classifiers. In International encyclopedia of the social and behavioral sciences, vol. 3, ed. by James Wright, 811-18. Oxford: Elsevier.

Grinevald, Colette, and Michel Bert. 2011. Speakers and communities. In The Cambridge handbook of endangered languages, ed. by Peter Austin, and Julia Sallabank, 45-65. Cambridge: Cambridge University Press.

Grinevald, Colette, and Frank Seifart. 2004. Noun classes in African and Amazonian languages: Towards a comparison. Linguistic Typology 8:243-85.

Harrison, Sheldon P. 1976. Mokilese reference Grammar. Honolulu: University of Hawai'i Press.

INSEE-ISEE. (2009). Recensement de la population de la Nouvelle-Calédonie en 2009. [http://www.isee.nc/population/population.html].

Izoulet, Jacques. 2005. Ouvéa: Histoire d'une mission catholique dans le Pacifique sud au XIXe siècle. Paris: L'Harmattan.

Lakoff, Gillian. 1986. Classifiers as a reflection of mind. In Noun classes and categorization, ed. by Colette Craig, 13-52. Amsterdam: John Benjamins.

Leenhardt, Maurice. 1946. Langues et dialectes de l'Austro-Mélanésie. Paris: Travaux et mémoires de l'Institut d'Ethnologie.

Lichtenberk, Frantisek. 1983. Relational classifiers. Lingua 60(2-3):147-76.

. 1985. Possessive constructions in Oceanic languages and in Proto-Oceanic. In Austronesian linguistics at the 15th Pacific Science Congress, ed. by Andrew Pawley and Lois Carrington, 93-140. Canberra: Pacific Linguistics.

- To appear. The diachrony of Oceanic possessive classifiers. In Diachrony of classification systems, ed. by William McGregor and Søren Wichmann. Amsterdam: John Benjamins.

Lynch, John, Malcolm Ross, and Terry Crowley. 2002. The Oceanic languages. Curzon Language Family Series. Richmond: Curzon.

Majid, Asifa. 2012. A guide to stimulus-based elicitation for semantic categories. In The Oxford handbook of linguistic fieldwork, ed. by Nicholas Thieberger, 54-71. Oxford: Oxford University Press.

Makihara, Miki. 2001. Modern Rapanui adaptation of Spanish elements. Oceanic Linguistics 40:191-223.

Marnita, Rina. 2016. Classifiers in Minangkabau: A typological study. Munich: LINCOM.

Meyerhoff, Miriam. 2006. Introducing sociolinguistics. Oxford: Routledge. -To appear. Possession marking in Nkep (East Santo, Vanuatu).

Moyse-Faurie, Claire. 1995. Le xârâcùù: Langue de Thio-Canala (Nouvelle-Calédonie): Éléments de syntaxe. Paris: Peeters.

- 2004. Recherches en linguistique océanienne. Mémoire de HDR. Université Paris IV-Sorbonne.

Moyse-Faurie, Claire, Jean-Claude Rivierre, and Jacques Vernaudon. 2012. Les langues kanak. In Atlas de la Nouvelle-Calédonie, ed. by Jacques Bonvallot, Jean- 
Christophe Gay, and Elisabeth Habert, 119-22. Marseille/Nouméa: IRD/Congrès de la Nouvelle-Calédonie.

Olness, Gloria. 1991. Semantic correlates of three morphosyntactic classifier types: A cross-linguistic survey. MA thesis, University of Oregon.

Osumi, Midori. 1995. Tinrin grammar. Oceanic Linguistics Special Publication No. 25. Honolulu: University of Hawai'i Press.

Ozanne-Rivierre, Françoise. 1976. Le iaai: Langue mélanésienne d'Ouvéa, NouvelleCalédonie: Phonologie, morphologie, esquisse syntaxique. Paris: Société d'études linguistiques et anthropologiques de France.

_. 1984. Dictionnaire iaai-français (Ouvéa, Nouvelle-Calédonie), suivi d'un lexique français-iaai. Paris: Société d'études linguistiques et anthropologiques de France.

. 1991. Incorporation of genitive relators in the languages of New Caledonia and the Loyalty Islands. In Currents in Pacific linguistics: Papers on Austronesian linguistics and ethnolinguistics in honour of George W. Grace, ed. by Robert Blust, 321-38. Canberra: Pacific Linguistics.

-1998. Le nyelâyu de Balade (Nouvelle-Calédonie). Paris: Peeters.

Païta, Yvonne, and Tadahiko Shintani. 1990. Grammaire de la langue de Païta. Nouméa: Société d'études historiques de la Nouvelle-Calédonie.

Payne, Doris, and Thomas Payne. 2014. A grammar of Panare. Leiden: Bril.

Ray, Sidney H. 1926. A comparative study of the Melanesian island languages. Cambridge: Cambridge University Press.

Rehg, Kenneth. 1998. Taking the pulse of Pohnpeian. Oceanic Linguistics 37:323-45.

Rehg, Kenneth, and Damian Sohl. 1981. Ponapean reference grammar. Honolulu: University of Hawai'i Press.

Rivierre, Jean-Claude. 1980. La langue de Touho: Phonologie et grammaire du cèmuhî, Nouvelle-Calédonie. Paris: Société d'études linguistiques et anthropologiques de France.

Rivierre, Jean-Claude, and Sabine Ehrhardt. 2006. Le bwatoo et les dialectes de la région de Koné, Nouvelle-Calédonie. Paris: Peeters.

Sankoff, Gilian. 2006 Apparent time and real time. In Encyclopedia of language and linguistics, 2nd ed., ed. by Keith Brown, 110-16. Oxford: Elsevier.

Tryon, Darrell. 1968. Iaai grammar. Canberra: Pacific Linguistics.

Turell, Teresa. 2003. Apparent and real time in studies of linguistic change and variation. Noves SL. Revista de Sociolingüística (tardor). Electronic publication. [Available from: http://www.gencat.cat/llengua/noves/noves/hm03tardor/docs/ turell.pdf].

UNESCO. 2003. Vitalité et disparition des langues. Paris. Electronic publication. [http://unesdoc.unesco.org/images/0018/001836/183699F.pdf].

Zubin, David, and Mitsuaki Shimojo. 1993. How "general" are general classifiers? With special reference to ko and $t s u$ in Japanese. Proceedings of the Nineteenth Annual Meeting of the Berkeley Linguistics Department / General Session and Parasession on Semantic Typology and Universals 19(1):490-502. 